\title{
Nefrotik Sendrom ve Tubbi Beslenme Tedavisi
}

\author{
Nephrotic Syndrome and Medical Nutrition Therapy
}

\section{Esra Köseler Beyaz ${ }^{1}$}

Geliş tarihi/Received: 27.02.2018 • Kabul tarihi/Accepted: 03.12.2018

\section{ÖZET}

Vücuttan aşırı protein kaybı ile karakterize bir durum olan nefrotik sendrom organizmada pek çok defekte neden olabilmektedir. Nefrotik sendromun tedavi edilememesi ile birlikte de geri dönüşümsüz böbrek yetmezliğine neden olarak, ilerleyen dönemde bireyin hayatını tehlikeye sokacak sağlık sorunlarının yaşanmasına yol açabilmektedir. Proteinüri, ödem ve köpüklü idrar nefrotik sendromun sıklıkla görülen belirtileri arasındadır. Nefrotik sendromun tedavisi tıbbi beslenme tedavisi, tıbbi tedavi, immün sistem baskılayıcı tıbbi tedavi kullanılarak yapılabilmektedir. Nefrotik sendromlu hastalarda progresif böbrek yetmezliğinin önlenebilmesi için tıbbi beslenme tedavisinin önemi büyüktür. Nefrotik sendromlu hastalarda azot dengesinin korunabilmesi için yeterli enerji vermek önemlidir. Yine kas kaybının ve malnütrisyonun önlenebilmesi, proteinürinin dengelenebilmesi açısından da yeterli protein sağlanmalıdır. Nefrotik sendromda görülen komplikasyonlarından birisinin de hiperlipidemi olması nedeni ile diyet yağının tür ve miktarının da önemli olduğu vurgulanmaktadır. Sonuç olarak, tedavi edilemediği takdirde böbrek yetmezliğine neden olabilecek nefrotik sendromun kontrol altında tutulmasında tıbbi beslenme tedavisinin öneminin büyük olduğu düşünülmektedir. Bu derleme ile de nefrotik sendromda tıbbi beslenme tedavisinin açıklanması amaçlanmıştır.

Anahtar kelimeler: Nefrotik sendrom, tıbbi beslenme tedavisi, proteinüri

\begin{abstract}
Nephrotic syndrome, a condition characterized by excessive protein loss from the body, can cause many defects in the organism. With not to treat nephroticsyndrome, it can lead to irreversible renal failure and may lead to health problems that may endanger the life of the individual in the later period. Proteinuria, edema, foamy urine are common symptoms of nephrotic syndrome. Thetreatment of nephrotic syndrome can be done by medical nutrition therapy, medical treatment, and immunosuppressive medical treatment. Medical nutrition therapy is of great importance for preventing progressive renal failure in patients with nephrotic syndrome. In patients with nephrotic syndrome, it is important to give enough energy to maintain the nitrogen balance. Adequate protein should be provided in order to prevent muscle loss and malnutrition and to balance proteinuria. Since one of the complications of nephrotic syndrome is hyperlipidemia, it is emphasized that the type and amount of dietary fat is also important. In conclusion, medical nutrition therapy is considered to be of great importance in the control of nephrotic syndrome which may cause kidney failure unless it can be treated. The aim of this review is to explain the medical nutrition therapy in nephrotic syndrome.
\end{abstract}

Keywords: Nephrotic syndrome, medical nutrition therapy, proteinuria

1. İletişim/Correspondence: Başkent Üniversitesi, Sağllk Bilimleri Fakültesi, Beslenme ve Diyetetik Bölümü, Ankara, Türkiye • E-posta: koseler@baskent.edu.tr 이 https://orcid.org/0000-0001-7713-7871 


\section{GíRIŞ}

Nefrotik sendrom, glomerüler geçirgenliğin artması sonucu, proteinüri, hipoproteinemi, hipoalbüminemi, periferal ödem, hiperlipidemi ile karakterize bir klinik tablodur. Son dönem böbrek hastalığına götürebilen bir süreçtir (1).

Proteinüri, göz çevresinde, yüzde, ayaklarda, bileklerde ve karında ödem, vücut ağırlığı artışı (sıvı retansiyonuna bağlı), köpüklü idrar, iştah kaybı, yüksek kan kolesterolü ve nefessizlik nefrotik sendromun sıklıkla görülen belirtileri arasındadır (2).

Nefrotik sendromun klinik tanımlanması, proteinüri (proteinüri $\geq 3.0-3.5 \mathrm{~g} / 24$ saat veya spot idrar protein), hipoalbüminemi (serum albümin $\leq 3.0 \mathrm{~g} / \mathrm{dL}$ ), serum total protein eksikliği (serum total protein $\leq 6.0 \mathrm{~g} /$ dL), ödem, dislipidemi, ciddi hiperlipidemi (total kolesterol >10 mmol/L), tromboembolizm, enfeksiyon, D vitamini eksikliğine bağlı kemik hastalıkları ve akut renal hasar varlığına göre belirlenmektedir (3).

Nefrotik sendrom, minimal değişiklik hastalığı, membranöz glomerülonefrit, fokal segmental glomerülosklerozis, immunoglobulin A nefropatisi, lupus, diyabet, hepatit B ve hepatit C, HIV gibi bazı enfeksiyonlar gibi pek çok hastalığa neden olabilmektedir (Tablo 1) (2).

\section{Tanı}

Nefrotik sendrom görünür belirti ve semptomların belirlenebilmesi için fiziksel muayene, böbrek hasarı ve diğer hastalıkların belirtilerinin belirlenebilmesi için kan ve üre testleri, görüntüleme testleri ve böbrek biyopsisi ile böbrek hastalığına ilişkin genetik bozuklukları değerlendiren genetik testlerin değerlendirilmesi ile teşhis edilmektedir. Çoğunlukla nefrotik sendromlu hastalar artmış idrar protein, kan üre azotu, kreatinin, total kolesterol, düşük dansiteli lipoprotein (LDL) kolesterol, çok düşük dansiteli lipoprotein (VLDL) kolesterol, apolipoprotein B, apolipoprotein C II, fibrinojen, azalmış hemoglobin, total protein, albümin, D vitamini, glomerüler filtrasyon hızl, antitrombin III, immunoglobulin G ve
Tablo 1. Nefrotik sendrom ile ilişkili hastalıklar (2)

Nefrotik sendrom ile ilişkili primer glomerüler hastalıklar

Minimal değişiklik hastalığ

Fokal ve segmentalglomeruloskleroz

Membranöz glomerülopati

Proliferatif glomerülonefrit

Membran proliferatif glomerülonefrit

Mezanjiyo proliferatif glomerülonefrit

IgM nefropatisi

IgA nefropatisi

Fibrillar glomerülopati

Konjenital podositanomalisi

Nefrotik sendromun ikincil nedenleri

Maligniteler (lenfomalar, solid tümörler)

İlaçlar ve nefrotoksinler (ağır metaller,

ACE inhibitörleri gibi.)

Enfeksiyonlar (bakteriyal, viral, protozoal, helmintik)

Neoplazi

Solid tümörler

Multiplemyeloma

Gebelik

Obezite

Kollajen vasküler hastalıklar (diabetes mellitus, amiloidoz, konjenital nefrotik sendrom)

Allerjenler

Hipotiroidizm

Kalp yetmezliği, perikardit

Romotoid poliartirit

*Ig: Immünoglobulin, ACE: Anjiotensin dönüştürücü enzim

diğer immunoglobilinler, komplement durumu ile karakterizedir (2).

\section{Tedavi}

Nefrotik sendromun tedavisi tıbbi beslenme tedavisi, tıbbi tedavi, immün sistem baskılayıcı tıbbi tedavi kullanılarak yapılabilmektedir. Ancak nefrotik sendromu ilerlemiş vakalarda böbrek hasralanması geliştiyse renal replasman tedavisi ve böbrek transplantasyonu da tedavi seçenekleri arasında yer almaktadır (2). 


\section{Steroid kullanımı}

Nefrotik sendromum tubbi tedavisinde, idrar protein düzeyini azaltmak, böbrek işlev kaybını önlemek, steroidresistant glomerülosklerozis/nefropati varlığında steroid tedavisine ek immunosupresif ajan kullanılabilmektedir.

\section{Diüretik (Derece B)}

Nefrotik sendromun tıbbi tedavisinde diüretikler vücuttaki ödem varlığını azaltmak için kullanılır. Oral verilen doz ödemin giderilmesinde yetersiz kalırsa, diüretik intravenöz uygulanabilmektedir.

\section{Statin (Derece C1)}

Nefrotik sendrom varlığı kronik dönemde lipit metabolizmasında bir takım değişikliklerin gerçekleşmesine neden olabilmektedir. Nefrotik sendromun tıbbi tedavisinde statinler, lipit metabolizması anormalliklerini önlemek için kullanılabilir.

\section{Albümin kullanımı (Derece C)}

Nefrotik sendromum tıbbi tedavisinde albümin kullanımı söz konusudur. Ancak hipoalbüminemi ve ödemi iyileştirmek konusunda yetersiz kalıp, hipertansiyonu tetikleyebilmektedir (4).

Renin anjiotensin sistem inhibitörleri, diüretikler, albümin ajanları, antiplatatelet ve antikoagülan ajanlar, statinler, ezentimibe, LDL düşürücüler, Ekstrakorporeal ultrafiltrasyon yöntemi, trimetoprimsulfametoksazol kombinasyonu, immunoglobulin desteği, antitüberküloz ilaçlar, hepatitis B virus tedavisi, prednizon, siklofosfamid, siklosporin, mikofenolat, furosemid, spironolakton, lisinopril, losartan gibi ajanlar da nefrotik sendromun tıbbi tedavisinde kullanılabilmektedir.

Renal perfüzyon üzerinde hemodinamik etkiler, ödem, hiperkalemi ve renal toksisiteye neden olabilmektedir (5).

\section{Tibbi Beslenme Tedavisi}

Nefrotik sendromda tıbbi beslenme tedavisinin amacı proteinürinin spesifik nedeninin belirlenmesi ve altta yatan hastalığın tedavisi, hastalarda ortaya çıkan hipoalbüminemi, ödem ve hipertansiyon gibi komplikasyonlar kontrol altına alınması, pozitif azot dengesi sağlanması ve malnütrisyon gelişiminin önlenmesidir (6).

\section{Enerji}

Nefrotik sendromlu hastalarda azot dengesinin korunması için $35 \mathrm{kkal} / \mathrm{kg} /$ gün enerji alımı yetişkin hastalarda idealdir. Steroid tedavisi alan bazı hastalarda iştahın artmasıyla vücut ağırlığında artış ve obezite görülebilir. Bu hastaların diyetinde enerji alımı mutlaka kontrol altında olmalıdır $(6,7)$.

\section{Protein}

Kas kaybı, ciddi artmış albümin turnoverı nefrotik sendromlu hastalarda büyük birer sorun olarak ortaya çıkmaktadır. Kanıt yetersizliğinden dolayı, bu hastalarda en uygun protein alımı net değildir. Düşük proteinli diyetler negatif nitrojen dengesi ve malnütrisyon için bir risk teşkil ettiği için önerilmemektedir (8).

Yüksek proteinli diyetin hipoalbüminemiyi düzeltmede etkili olmadığını göstermiştir. Aksine yüksek proteinli diyet alımı ile birlikte glomerüler hiperfiltrasyon ve artmış proteinüri görülmüştür. Hayvansal proteine kıyasla, bitkisel proteinlerin proteinüriyi azaltma konusunda etkili olduğu görülmüştür. Düşük proteinli diyetlerin $\quad(<0.8 \mathrm{~g} / \mathrm{kg} /$ gün) ise nefrotik sendromlu hastalarda malnütrisyon açısından risk teşkil ettiği ifade edilmektedir. 0.8$1.0 \mathrm{~g} / \mathrm{kg} / \mathrm{gün}$, tercihen balık ve bitkisel protein tercih edilmelidir (9).

Nefrotik sendromda protein kısıtlamasının etkinliği tartışmalıdır. Japon Nefroloji Topluluğu Kılavuzları'na göre minimal değişiklik nefrotik sendromda 1.0-1.1 g/ $\mathrm{kg} / \mathrm{gün}$, diğer nefrotik sendromlu hastalarda $0.8 \mathrm{~g} / \mathrm{kg} /$ gün protein alımı önerilmektedir. Nitrojen dengesini

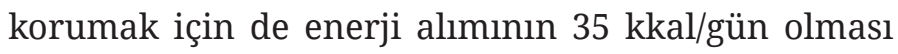
gerektiğini belirtmektedir (4). 
Lim ve arkadaşları (10) ile Maroni ve arkadaşları (11) tarafindan yapılan çalışmalarda, hastalara sırasıyla protein içeriği $0.9 \mathrm{~g} / \mathrm{kg} / \mathrm{gün}$ ve $0.8 \mathrm{~g} / \mathrm{kg} / \mathrm{gün}$ olan diyetler uygulanarak pozitif azot dengesinin korunduğu ve protein yıkımının azaldığı saptanmıştır.

Nefrotik sendromda diyet proteini olarak soya proteinin kullanıldığı bir araştırmada, soya proteininde bulunan izoflavonlarm (genistein) nefrotik sendromun histopatolojisini ve oksidatif durumu olumlu etkilediği saptanmıştır (12).

Kronik nefrotik sendromlu ratlarda iki ay süresince \%20 soya proteini içeren diyet uygulandığında yağ asit sentaz, hidroksi-metil glutaril-CoAredüktaz ekspresyonlarında düzelme olduğu belirlenmiştir. Soya proteini hipolipidemik etki göstermiştir (13).

\section{Yăg}

Nefrotik sendromun komplikasyonlarından birisi de hiperlipidemi varlığıdır. Hiperlipideminin ve serum kolesterol miktarındaki artışın engellenmesi adına da diyet yağının tür ve miktarının önemli olduğu vurgulanmaktadır. Yağdan alınan enerjinin \%30’u geçmemesi gerektiği ve kolesterol ve doymuş yağ asidi alımının sınırlandırılması gerektiği belirtilmektedir (14). Samira ve arkadaşlarının (15) yaptığı çalışmada, omega-3 yağ asidi desteği ile hastaların postprandiyal şilomikron yoğunluğunda ve postprandiyal lipemik yanıtında azalmalar olduğu saptanmıştır.

Diyet yağ ve kolesterol kısıtlamasının glomerüler hastalıklarda, özellikle de nefrotik sendromda hiperlipidemi üzerine ılımlı etkilere sahip olduğu ifade edilmektedir (16). Nefrotik sendromun tıbbi beslenme tedavisinde yağ kısıtlamasının dislipidemiyi ve yaşam prognozunu iyileştirmesini konu alan bir çalışmada, nefrotik sendromlu hastalarda dislipidemi tedavisinde yağ kısıtlı diyet uygulanabileceğini(düşük kolesterollü yiyecekler, sebzeler, kurubaklagiller gibi posadan zengin örüntünün yer aldığı diyet dislipidemiyi iyileştirir), ancak yağ kısıtlı diyetin nefrotik sendrom prognozunu iyileştirdiğine dair kanıtların yeterli olmadığı belirtilmektedir (Derece C1) (17).

\section{Karbonhidrat}

Nefrotik sendromlu hastalarda alınan protein miktarına göre karbonhidrat alımı değişmektedir. Proteinlerin enerji olarak kullanımını engellemek için diyet karbonhidrat alımı yeterli olmalıdır. Kompleks karbonhidrat alımının arttırılması gerektiği ifade edilmektedir.

\section{Sodyum}

Nefrotik sendromda ödemi azaltmak için sodyum kısıtlaması gereklidir. Nefrotik sendromlu bazı hastalarda renin anjiotensin sistem engellenmiştir ve artial natriüretik peptit düzeyi artmıştır (atrial natriüretik hormon anormal cevabı vardır). Bu yüzden sodyum tutulumu da bu hastalarda artabilmektedir (17).

\section{Antioksidanlar}

Serbest radikallerin böbrek işlevleri üzerinde de zararı büyüktür. Serbest radikaller, glomerüler membran hasarında, glomerüler geçirgenliği değiştirerek protein geçişinin artmasında ve glomerüler hemodinamizmin değişmesinde rol oynamaktadır. Serbest radikal artışı ile nefrotik sendromun ilerleyen aşamalarında görülebilecek progresif böbrek hasarı artmaktadir.

Antioksidan özelliği olan selenyum ve $C$ vitamininin yeterli düzeylerde alınması böbrek hemodinamizmi açısından önemlidir (18).

Yapllan bir araştırmada, nefrotik sendromlu yetişkin bireylerin, plazma selenyum düzeyi, eritrosit ve plazma glutatyon peroksidaz aktiviteleri, eritrosit süperoksit dismutaz aktiviteleri, eritrosit ve plazma malondialdehit düzeyleri araştırılarak oksidatif stres durumları ortaya konulmuştur. Nefrotik sendromlu hastalarm antioksidan sistemlerinde anormallikler belirlenmiştir (19). 
Nefrotik Sendromda Görülen Bazı Metabolik Değişikliklere Yönelik Beslenme Önerileri

\section{Ödem}

Nefrotik sendromda ödemin tedavisinde kılavuz veya randomize kontrollü çalışma yoktur. Günlük 100 mmoL altında diyet sodyum alımı önerilmektedir. Sıvı alımı olarak da günlük 1.5 L sıvının sağlanması gerektiği belirtilmektedir. Tıbbi tedavi olarak diüretiklerin kullanımı söz konusudur. Nefrotik sendromda ödemin yavaş yavaş iyileştirilmesi gerektiği belirtilmektedir. Ödemin tedavisinde 0.5-1.0 kg/gün kayıp hedeflenmelidir. Aksi takdirde agresif diürez elektrolit dengesizliğine, akut renal hasara, hemokonsantrasyona bağlı tromboembolizme neden olabilmektedir (20-22).

\section{Kan basincı}

Nefrotik sendromda kan basıncı yüksekliği görülebilmektedir. Bu yüzden nefrotik sendromun tedavisinde kan basıncı kontrolü sağlanmalıdır. Sistolik kan basıncının $125 \mathrm{mmHg}$, diyastolik kan basıncinın $75 \mathrm{mmHg}$ olmasi hedeflenmektedir. Antihipertansif ilaçların etkinliğini arttırmak için de 6 g/gün tuz kısıtlamasının etkinliğinin önemi vurgulanmaktadır $(9,23)$.

\section{İmmün sistem disfonksiyonu}

Nefrotik sendrom bozulmuş immün cevap ile karakterizedir. Nefrotik sendromda, mitojenlerin uyarmasına karşılık, T-lenfositlerde azalma vardır. Ayrıca, dolaşımdaki humoral etmenler ve lenfokinlerde dengesizlik ve lenfosit alt grup dağılımlarında (Th1/Th2) düzensizlikler vardır (24).

\section{SONUÇ VE ÖNERILER}

Ciddi proteinüri durumu ile karakterize nefrotik sendrom tedavi edilemediği takdirde böbrek yetmezliğine kadar neden olarak birey için ciddi bir morbidite ve mortalite nedeni olabilmektedir. $\mathrm{Bu}$ yüzden tıbbi beslenme tedavisi, tıbbi tedavi, immün sistem baskılayıcı tıbbi tedavi kullanılarak tedavi edilen nefrotik sendromun kontrolünde ve tedavisinde tıbbi beslenme tedavisinin öneminin büyüklüğü ifade edilmektedir.

Çıkar çatışması - Conflict of interest: Yazarlar çıkar çatışması olmadığını beyan ederler. - The authors declare that they have no conflict of interest.

\section{KAYNAKLAR}

1. Schwarz A. New aspects of the treatment of nephrotic syndrome. J Am Soc Nephrol 2001;12:44-7.

2. National Kidney Foundation. Available at: https: //www. kidney. org/ atoz/ content/ nephrotic Accessed December 12, 2018.

3. Richard PH, Goldsmith DJA. Nephrotic syndrome in adults. BMJ 2008;336:1185-9.

4. Nishi S, Ubara Y, Utsunomiya Y, Okada K, Obata Y, Kai $\mathrm{H}$, et al. Evidence-based clinical practice guidelines for nephrotic syndrome. Clin Exp Nephrol 2016;20:342-70.

5. Schwarz A. New aspects of the treatment of nephrotic syndrome. J Am Soc Nephrol 200112:44-7.

6. Molfino A, Don BR, Kaysen GA. Nutritional and nonnutritional management of the nephrotic syndrome. In:Kopple J,Massry S, Kalantar Zadeh K,editors. Nutritional Management of Renal Disease. 3rd ed. Academic Press; 2013. p. 393-413.

7. Kaku Y, Ohtsuka Y, Komatsu Y. Clinical practice guideline for pediatric idiopathic nephrotic syndrome: General Therapy. Clin Exp Nephrol 2015;19(1):34-53.

8. Richard PH, Goldsmith DJA. Nephrotic syndrome in adults. BMJ 2008;336:1185-9.

9. De Seigneux S, Martin P. Management of patients with nephrotic syndrome. Swiss Med Wkly 2009;139:416-22.

10. Lim VS, Wolfson M, Yarasheski KE. Leucine turnover in patients with nephrotic syndrome: evidence suggesting body protein conservation. JASN 1998;9(6):1067-73.

11. Maroni BJ, Staffeld C, Young VR. Mechanisms permitting nephrotic patients to achieve nitrogene quilibrium with a protein-restricted diet. ASCI 1997;99(10): 2479-87. 
12. Javanbakht MH, Sadria R, Djaali M. Soy protein and genistein improves renal antioxidant status in experimental nephrotic syndrome. Nefrologia 2014;34(4):483-90.

13. Tovar AR, Murgui'a F, Cruz C, Herna'ndez-Pando R, Aguilar-Salinas CA, Pedraza-Chaverri J, et al. A soy protein diet alters hepatic lipid metabolism gene expression and reduces serum lipids and renal fibrogenic cytokines in rats with chronic nephrotic syndrome. J Nutr 2002;132: 2562-69.

14. Bagga A. Revised guidelines for management of steroid-sensitive nephrotic syndrome. Indian J Nephrol 2008;18(1):31-9.

15. Bell S, Cooney J, Packard JC. Omega-3 fatty acids improve postprandial lipaemia in patients with nephrotic range proteinuria. Atherosclerosis 2009;205:296-301.

16. Eknoyan G. KDIGO Clinical practice guideline for glomerulo nephritis. Official Journal of the International Society of Nephrology. Available at: http://www.kidneyinternational.org Accessed September 25, 2018.
17. Nishi S, Ubara Y, Utsunomiya Y, Okada K, Obata Y, Kai $\mathrm{H}$, et al. Evidence-based clinical practice guidelines for nephrotic syndrome. Clin Exp Nephrol 2016;20:342-70.

18. Mishra OP, Gupta AK, Prasad R. Antioxidant status of children with idiopathic nephrotic syndrome. Child Nephrol Urol 2011;26: 251-56.

19. Bulucu F, Vural A, Aydin A, Sayal A. Oxidative stress status in adults with nephrotic syndrome. Clin Nephrol 2000;53(3):169-73.

20. Kodner C. Nephrotic syndrome in adults: Diagnosis and management. Am Fam Physician. 2009;80(10):1129-34.

21. Hull RP, Goldsmith DJA. Nephrotic syndrome in adults. BMJ 2008;336:1185-89.

22. Dorhout Mees EJ. Does it make sense to administer albumin to the patient with nephrotico edema? Nephrol Dial Transplant 1996;11:1224-26.

23. Remuzzi G, Benigni A, Remuzzi A. Mechanisms of progression and regression of renal lesions of chronic nephropathies and diabetes. J Clin Invest 2006;116(2):288-96.

24. Stachowski J, Barth C, Michalkiewicz J, Krynicki T, Runowski D, Lewandowska-Stachowiak M, et al. Th1/ Th2 balance and CD45-positive T cell subsets in primary nephrotic syndrome. Pediatr Nephrol 2000;14:779-85. 